Marek Jeziorański*

Lublin

\title{
Aksjologiczne orientacje w pedagogice Kazimierz Dolny, 27-29 maja 2013 roku
}

W dniach od 27 do 29 maja 2013 roku w Kazimierzu Dolnym nad Wisłą odbyła się Ogólnopolska Konferencja Naukowa pod tytułem: Aksjologiczne orientacje $w$ pedagogice. Konferencja została zorganizowana przez zespół pracowników Katedry Pedagogiki Ogólnej Katolickiego Uniwersytetu Lubelskiego Jana Pawła II, któremu przewodniczył ks. dr hab. Marian Nowak, prof. KUL. Konferencja objęta była patronatem KNP PAN, a w skład Komitetu Naukowego weszli: prof. dr hab. Teresa Hejnicka-Bezwińska, prof. dr hab. Katarzyna Olbrycht, prof. dr hab. Stanisław Palka, prof. dr hab. Bogusław Śliwerski, prof. dr hab. Mirosław J. Szymański, prof. dr hab. Andrzej Bogaj, prof. dr hab. Roman Leppert, prof. dr hab. Ryszard Bera, prof. dr hab. Krystyna Ablewicz, prof. dr hab. Janina Kostkiewicz, prof. dr hab. Janusz Kirenko, prof. dr hab. Dariusz Kubinowski, prof. dr hab. Krystyna Chałas, prof. dr hab. Alina Rynio oraz prof. dr hab. Lucyna Dziaczkowska.

Konferencja wpisała się w prace podejmowane na gruncie pedagogiki polskiej przez Zespół Pedagogiki Ogólnej, działający od 1995 roku pod patronatem KNP PAN. Jest on szeroką płaszczyzną pozwalającą na podejmowanie zagadnień związanych z podstawami pedagogiki i podstawowymi problemami wychowania, które związane są z sytuacją pluralizmu i demokratyzacji, jak również pozwalająca na poszukiwanie podejść i rozwiązań interdyscyplinarnych i systemowych. Zespół Pedagogiki Ogólnej od początków swojej działalności podejmował problemy z zakresu podstaw pedagogiki, w kolejnych etapach wyznaczanych konferencjami Zespołu w Bydgosz-

* Ks. dr Marek Jeziorański jest asystentem w Katedrze Pedagogiki Ogólnej Katolickiego Uniwersytetu Lubelskiego Jana Pawła II w Lublinie. 
czy (trzykrotnie), Częstochowie, Kielcach i dwukrotnie z inicjatywy Katedry Pedagogiki Ogólnej Instytutu Pedagogiki KUL, których efektem są publikacje: 1. T. Kukołowicz, M. Nowak (red.), Pedagogika ogólna. Problemy aksjologiczne, RW KUL, Lublin 1997; 2. M. Nowak, P. Magier, I. Szewczak (red.), Antropologiczna pedagogika ogólna, Wydawnictwo KUL, Wydawnictwo GAUDIUM, Lublin 2010.

Zamiar podjęcia orientacji aksjologicznych w uprawianiu pedagogiki, częściowo nawiązując do konferencji i publikacji wydanej przed 15 laty w KUL, jest zorientowany szerzej niż tylko na zarysowanie aksjologicznych uwarunkowań uprawiania pedagogiki. Za cel stawia sobie ustalenie pewnej mapy orientacji aksjologicznych uprawiania pedagogiki w Polsce i w krajach sasiednich i wskazanie na podstawy metodologiczne, filozoficzne, antropologiczne, ideowe, światopoglądowe itp. tychże orientacji z jednoczesnymi możliwościami ich współdziałania i ubogacania się.

Konferencji postawiono następujące cele główne:

1. Wymiana poglądów i podjęcie debaty na temat aksjologicznych uwarunkowań uprawiania pedagogiki ogólnej w Polsce.

2. Tworzenie mapy aksjologicznych orientacji w pedagogice ogólnej w Polsce.

3. Wskazanie na uwarunkowania $\mathrm{w}$ tworzeniu aksjologicznej pedagogiki ogólnej.

4. Prezentacja możliwości interdyscyplinarnego dialogu nad uwarunkowaniami aksjologicznymi uprawiania pedagogiki.

Konferencja została uroczyście otwarta przez dyrektora Instytutu Pedagogiki KUL a zarazem przewodniczącego Komitetu Organizacyjnego Konferencji, ks. dr hab. Mariana Nowaka, prof. KUL, który powitał wszystkich uczestników oraz wprowadził w zagadnienia tematyczne i organizacyjne konferencji. Poza sesją referatów otwierających konferencja składała się z ośmiu sesji tematycznych następujących po sobie.

Pierwszym wystapieniem otwierającym był głos prof. dr hab. Teresy Hejnickiej-Bezwińskiej (UKW w Bydgoszczy), Przewodniczącej Zespołu Pedagogiki Ogólnej KNP PAN, która podjęła zagadnienie pt. Problem wartości $i$ wartościowania $w$ pedagogice na poszczególnych etapach jej rozwoju. Punktem wyjścia podejmowanej problematyki było przedstawienie mapy kulturowej z wyliczeniem poszczególnych jej elementów, w skład których wchodzi również edukacja. Wszystkie komponenty ukazanej mapy mają istotne znaczenie w budowaniu tożsamości ,ja” oraz „my” poszczególnych osób. To przypomnienie podkreśliło ważność społeczną podejmowanej przez konferencję tematyki oraz pozwoliło w sposób uporządkowany ukazać współczesne zmiany kulturowe i wynikające $\mathrm{z}$ nich ewentualne zagrożenia i zadania edukacyjne. Do podstawowych zmian w obszarze kultury 
Prelegentka zaliczyła: 1. zwrot lingwistyczny, 2. zwrot paradygmatyczny, 3. zwrot refleksyjny i hermeneutyczny oraz 4. zwrot etyczny (ze szczególnym wskazaniem na programy oświatowe).

Drugi referat wygłosił prof. dr hab. Stanisław Palka (UJ w Krakowie) nt. Zamierzonej i rzeczywistej użyteczności uprawiania pedagogiki ogólnej. Podjęte w nim zagadnienia ukazywały miejsce pedagogiki ogólnej w systemie nauk pedagogicznych i jej relację do pedagogik szczegółowych. Profesor wymienił trzy podstawowe schematy ujmowania relacji pedagogiki ogólnej do pedagogik szczegółowych: 1. pedagogika ogólna jako supernauka pedagogiczna, której zadaniem jest przygotowywanie narzędzi teoretycznych i metodologicznych dla pedagogicznych nauk szczegółowych; 2. pedagogika ogólna jako jedna z dyscyplin pedagogicznych oraz 3. pedagogika ogólna jako dyscyplina podrzędna względem innych dyscyplin pedagogicznych a przez to nieraz określana jako niepotrzebna, bądź też ograniczana do zakresu polityki oświatowej czy metodyki. Pierwsze rozumienie pedagogiki ogólnej wydaje się być najbardziej właściwym ujęciem. Dzięki niemu zachowana jest jedność pedagogiki jako nauki a teoretyczne badania naukowe podejmowane przez tak rozumianą pedagogikę ogólną mogą być egzemplifikowane przez poszczególne dyscypliny pedagogiczne z uwzględnieniem własnych założeń badawczych.

Po wykładach otwierających rozpoczęto pace w sesjach tematycznych. Od razu warto jednak zaznaczyć, że duża liczba zaplanowanych wystapień (81) nie pozwala na szczegółowe omówienie każdego referatu. Zostaną one ukazane w perspektywie problemów podejmowanych w poszczególnych sesjach. Już w tym momencie można jednak wskazać, że podejmowane zagadnienia ukazywane zostały - co wprawdzie nie było planowane przez organizatorów a wyodrębniło się w czasie referatów i podejmowanych dyskusji - w dwóch przenikających się obszarach: w obszarze pedagogiki ogólnej i w obszarze pedagogik szczegółowych. Wybór podejmowanej perspektywy zależał od prelegenta.

Pierwszej sesji, zatytułowanej: Wartości - Pedagogika - Pedagogika ogólna przewodniczyła prof. dr hab. Teresa Hejnicka-Bezwińska. Prace $\mathrm{w}$ tej sesji rozpoczęto od zasygnalizowania dwóch podstawowych dylematów: 1. wychowywać człowieka, który jest nastawiony na wartości pragmatyczne czy człowieka ideowego oraz 2. czy kierować się wartościami, które dadzą normy, czy też kierować się norami negocjacyjnymi (prof. dr hab. Katarzyna Olbrycht, Orientacja/e aksjologiczne w pedagogice w świetle perspektywy personalistycznej)? W ramach tej sesji podejmowano również rozważania nad „orientacjami”, ich istota, rodzajami i znaczeniem dla wychowania (prof. dr hab. Andrzej Sowiński, Aksjologiczna orientacja jako kategoria pedagogiczna - głos $w$ dyskusji) oraz nad różnymi klasyfikacjami 
wartości, ukazując zarazem, że wybór konkretnych wartości realizowanych w procesie wychowawczym nie jest obojętny dla efektu wychowawczego może bowiem nieść z sobą również zagrożenia (prof. dr hab. Janusz Gajda, Wartości podstawq edukacji w konfrontacji z pedagogikq ideatów i pedagogika życia). Wskazano również te obszary, które wymagają jeszcze refleksji pedagogicznej w zakresie podejmowanej problematyki (prof. dr hab. Andrzej Bogaj, Zaniedbane obszary wychowania jako wyzwanie dla pedagogiki ogólnej). Podjęto tu także zagadnienie analizy konkretnych wartości w wychowaniu. Ukazane zostały: tolerancja (prof. dr hab. Jerzy Nikitorowicz, Tolerancja jako wartość w naukach o wychowaniu), inkluzywny model readaptacji społecznej (prof. dr hab. Andrzej Bałandynowicz Inkluzyjny model integracyjno-kognitywnego procesu readaptacji społecznej wsparty na wartościach osobowych, społecznych i kulturowych) oraz czas jako wartość (prof. dr hab. Barbara Kromolicka, Bank czasu - na przekór gubionej wartości).

Sesja druga prowadzona była przez prof. dr hab. Andrzeja Bogaja i koncentrowała się wokół zagadnienia: Wartości - Kultura - Nauki o wychowaniu. Można wyróżnić w niej dwa zasadnicze tematy: analiza wybranych wartości oraz kategoria „wartościowania” w pedagogice. Zwłaszcza jeśli chodzi o drugi obszar tematyczny, to podejmowane tu problemy dotyczyły podstaw rozumienia samej pedagogiki jako nauki i refleksji nad (koniecznością) obecności w niej wymiaru normatywnego. Uzupełniający się dwugłos stanowiły wystapienia prof. dr hab. Mirosławy Nowak-Dziemianowicz (Kryzys w kulturze a edukacja. Normatywne uwiktania pedagogiki), która w swoim wystapieniu podjęła zagadnienie relacji pedagogiki do normatywności, wskazując zarazem na te obszary badań pedagogicznych, gdzie istnieje niebezpieczeństwo niewłaściwego posługiwania się normatywnością. Pewnego rodzaju uzupełnieniem podjętego wcześniej tematu było wystąpienie prof. dr. hab. Dariusza Kubinowskiego (Wartościowanie w badaniach pedagogicznych wobec dogmatu nauki ,, wolnej od wartości”), który z kolei w wartościowaniu widział istotny element pedagogiki, z którego ta nauka nie może zrezygnować. W ramach tej sesji zaprezentowana została pierwsza próba nakreślenia mapy aksjologicznej pedagogiki (dr Andrzej Ryk, Próba systemowego ujęcia aksjologicznych podstaw w pedagogice). Wśród zaprezentowanych wartości ukazane zostały: antropologia i pedagogia w perspektywie Gestalt (prof. dr hab. Krystyna Ablewicz), kształcenie uniwersyteckie (prof. dr hab. Ewa Rodziewicz), nadzieja (ks. prof. dr hab. Stanisław Chrobak) oraz rozumienie jako kategoria pulsująca (dr Dorota Jankowska).

Zagadnienia podejmowane w sesji trzeciej oscylowały wokół Historycznych przestanek aksjologii w pedagogice. Sesja, prowadzona przez prof. dr hab. Stanisława Palkę, podjęła takie tematy jak: orientacje aksjologicz- 
ne w międzywojennej pedagogice katolickiej (prof. dr hab. Janina Kostkiewicz), wkład Zygmunta Mysłakowskiego, Kazimierza Sośnickiego oraz Stefana Kunowskiego w problematykę aksjologiczną pedagogiki ogólnej (prof. dr hab. Lucyna Dziaczkowska) czy też prawda jako wartość w epistolografii Hildegardy z Bingen (prof. dr hab. Małgorzata Kowalewska). Główna oś badania historycznej myśli pedagogicznej w tej sesji nie zamykała jej referatów do samego jedynie opisu. Znalazły się tu również wystapienia, które - na bazie analizy historycznej - formułowały postulaty względem współczesnej myśli pedagogicznej i wychowawczej (ks. prof. dr hab. Jan Śledzianowski, Powinność wspótczesnej pedagogiki - odbudowa wartości i sensu życia ludzkiego; prof. dr hab. Elżbieta Gaweł-Luty, Aksjologiczne podstawy we wspótczesnej pedagogice; dr Teresa Zawojska, Jakiej teorii wartości potrzebuje uniwersalna pedagogia?).

Kolejna sesja podejmowała zagadnienie badań pedagogicznych prowadzonych w inspiracji filozoficznej. Filozofia jest ważną nauką pomocniczą dla pedagogiki, zwłaszcza pedagogiki ogólnej. To z niej wyłoniła się pedagogika i ona też od samego początku stanowiła inspirację dla badań i działalności pedagogicznej. Podczas tej konferencji nie mogło więc zabraknąć $\mathrm{i}$ tego odniesienia. Tematem sesji była Filozoficzna inspiracja w aksjologii wychowania i była ona prowadzona przez prof. dr hab. Katarzynę Olbrycht. W wystapieniach wskazywano zarówno na konkretnych filozofów i myślicieli, którzy zainspirowali myśl pedagogiczną prelegentów (M. Gogacz - dr Jarosław Horowski, Aksjologia w edukacji i pedagogice - wartość czy problem?; J. Tischner - dr Andrzej Gołębiowski, Wychowanie do szczęścia spotkanie pedagoga z Tischnerowska koncepcja czlowieka agatologicznego; W. Brezinka - ks. dr Mariusz Sztaba, Aretologia jako fundament aksjologii $w$ realistycznym wychowaniu), jak i podejmowano analizę wybranych zjawisk w perspektywie filozoficzno-pedagogicznej. Można tu wymienić między innymi referaty prof. dr. hab. Jarosława Gary (Graniczność doświadczenia ludzkiego i jej implikacje pedagogiczne), dr Agnieszki Salamuchy (Czy istnieje charakter moralny? Między etyka cnót a etyka sytuacji), dr Anny Walczak (Etyka pedagogicznej codzienności jako odpowiedź na ,nieuchwytnq uniwersalność"), o prof. dr. hab. Romana Jusiaka (Chrześcijańskie wartości społeczne a rozwój osobowy), dr. Rafała Włodarczyka (Rygor obowiqzków w drodze ku odległym szczytom. Szkic z deontologii pedagogicznej i pedagogii azylu), dr Marty Kowalczuk-Walędziak (Spoleczna sprawczość działania pedagogicznego: między zawodowstwem a społecznym posłannictwem) czy też dr Marii Boużyk (Aksjologiczna mapa kultury).

Sesja piąta i szósta podejmowały zagadnienia obecności wartości we współczesnych sytuacjach wychowawczych. Sesja piąta (Aksjologia wspótczesnych sytuacji wychowawczych) prowadzona była przez prof. dr hab. An- 
drzeja Bałandynowicza a następna (Wartości i antywartości wspótczesnego zycia i wychowania) przez ks. prof. dr. hab. Mariana Nowaka. Podejmowane tu obszary tematyczne obejmowały bardzo szerokie spektrum zainteresowań referujących pedagogów. Do najczęściej podejmowanych zagadnień należały wartości i ich zagrożenia w obszarze: środowiska pracy (dr Maria Czechowska-Bieluga, Orientacja na wartości adeptów pracy socjalnej; dr Małgorzata Bogaj, Wartości wspótczesnej młodzieży a ich kariery zawodowe; dr Beata Jakimiuk, Aksjologiczny wymiar poradnictwa edukacyjno-zawodowego), środowiska wychowania rodzinnego (dr Danuta Opozda, Aksjologiczna problematyka wychowania w rodzinie-perspektywa metodologiczna; mgr Agnieszka Gandzel, Rola rodziców w wychowaniu dzieci do wartości muzyki), pedagogiki resocjalizacyjnej (dr Anna Kieszkowska, Rodziny uwięzionych - powinności i zadania spoleczeństwa otwartego; dr Tadeusz Sakowicz, Człowieczeństwo przestępcy a przestępczość człowieka - dylematy płynnej ponowoczesności; ks. dr Zbigniew Iwański, Orientacje aksjologicz$n e$ w resocjalizacji; dr Tomasz Wach, Recydywiści penitencjarni wobec własnej przyszłości), innych środowisk wychowawczych (dr Józef Placha, Znaczenie aksjologii pedagogicznej w integralnej rewalidacji osób z niepetnosprawnościa; dr Agnieszka Jaworska, Aksjologiczne założenia działalności katolickich uniwersytetów ludowych w Polsce w latach 1989-2004; dr Dorota Bis, Media jako narzędzie kreowania wartości i antywartości) oraz zagadnienia dotyczące badań nad wartościami w ogóle bądź w wybranych uwarunkowaniach (np. dr Krzysztof K. Przybycień, Aksjologiczny wymiar autokreacji; mgr Natalia Rapa, Innowacyjność jako wartość w edukacji; mgr Konrad Sawicki, Zdolności ludzkie w ujęciu Marthy C. Nussbaum jako wartości w procesie wychowania; dr Piotr Magier, Wartości pedagogiczne $i$ wartości w pedagogice - próba zarysu problematyki).

$\mathrm{Na}$ ostatni dzień konferencji (29.05.13 - środa) zaplanowane zostały dwie sesje: Teoretyczny model ujęć wartości w działalności wychowawczej (sesja siódma) pod przewodnictwem prof. dr hab. Elżbiety Gaweł-Luty oraz Etos $i$ odpowiedzialność za/wobec wartości (sesja ósma) pod przewodnictwem prof. dr hab. Krystyny Chałas. W pierwszej z nich prelegenci dokonywali prezentacji opracowanych teoretycznych ujęć wartości bądź też aplikacji wybranych modeli aksjologicznych do działalności wychowawczej szczególnie im bliskiej. I tak oto zaprezentowany został model aksjologiczny obecny w pedagogice szkolnej (prof. dr hab. Krystyna Chałas, Struktury aksjologiczne w pedagogice szkolnej), ukazane zostało rozumienie wartości w oparciu o teorię V. E. Frankla (dr Anna Lendzion, Wartości i wartościowanie w logoterapii V. E. Frankla a kryzysy egzystencjalne młodzieży), czy też w odniesieniu do przyjętych założeń konstytuujących wspólnotę międzyosobową (ks. dr Marek Jeziorański, 'Wspólnota'w kontekśsie edukacyjnym 
- od jej wartości do konieczności). Poza tym znaczna część pozostałych referatów poświęcona była problematyce aksjologicznej rodziny (mgr Wioleta Adamczyk-Bębas, Wartość dziecka w życiu matżeństwa i rodziny; dr Sylwester Bębas, Matżeństwo, rodzina i rodzicielstwo jako wartość we wspótczesnym spoteczeństwie; dr Anna Mitręga, Odpowiedzialność jako wartość we wspótczesnym wychowaniu rodzicielskim; dr Sabina Zalewska, Wartości we wspótczesnej rodzinie. Pomiędzy deklaracja a czynem) oraz analizie wybranych przez siebie obszarów aksjologicznych (dr Dorota Skrocka, Przebaczenie jako wartość pedagogiczna; dr Paula Wiążewicz-Wójtowicz, O doświadczaniu wartości estetycznych - komunikat z badań; dr Bartłomiej Gołek, Samoksztaltowanie czlowieka jako wartość poznawcza pedagogiki ogólnej).

W ostatniej sesji zaprezentowanych zostało pięć referatów. Podejmowały one zagadnienia: kultury pedagogicznej (dr Małgorzata Biedroń, Kultura pedagogiczna jako wartość deklarowana i realizowana. Rodzice wobec podnoszenia własnych kompetencji wychowawczych), systemu wartości młodzieży (mgr Patrycja Miśko, Dymensja ,indywidualizm-kolektywizm” jako wskaźnik systemu wartości wspótczesnej młodzieży), sytuacji społecznej - zwłaszcza w odniesieniu do opieki nad dzieckiem - w kraju zniszczonym wojną bratobójczą (ks. dr Zbigniew Babicki, Moralne aspekty opieki nad dzieckiem osieroconym $w$ Rwandzie) oraz wykorzystania nowych form edukacyjnych (mgr Hubert Szczepaniuk, Aksjologiczne aspekty celów e-learningu).

Ostatni referat wygłosił przewodniczący Komitetu Organizacyjnego Konferencji, ks. prof. dr hab. Marian Nowak (Kontury mapy wspótczesnych orientacji aksjologicznych $w$ pedagogice). Prelegent przedstawił $\mathrm{w}$ nim przede wszystkim własne badania nad orientacjami aksjologicznymi w pedagogice. Odniósł się również do treści prezentowanych we wszystkich sesjach konferencyjnych, które wkomponował w zaproponowaną przez siebie mapę aksjologiczną pedagogiki. Starając się pokazać wagę zagadnień aksjologicznych dla pedagogiki, a zarazem zamykając konferencję, ks. prof. M. Nowak posłużył się następującym zdaniem V. E. Frankla: „Nie mówmy człowiekowi, kim on jest, ale kim powinien być". Należy również zaznaczyć, że w tym wystapieniu zostało przypomniane, iż konferencja wpisuje się w szerszy nurt badawczy Katedry Pedagogiki Ogólnej KUL oraz Zespołu Pedagogiki Ogólnej KNP PAN. To natomiast oznacza, że potrzebne są kolejne „kroki” naukowego namysłu. Po refleksji nad antropologicznymi podstawami pedagogiki ogólnej (2010 rok), jak i obecnie nad aksjologicznymi orientacjami w pedagogice, kolejnym zagadnieniem może być analiza podstaw metodologicznych, ideowych czy światopoglądowych pedagogiki.

Szczególnym elementem tej konferencji było nowatorskie wykorzystanie współczesnych środków medialnych. Było to możliwe dzięki portalowi 
Academicon (academicon.pl), który stawia sobie za cel integrowanie i promowanie środowiska naukowego w sieci. Niektóre wykłady konferencyjne były na bieżąco transmitowane w sieci, co dało możliwość poszerzenia grona osób chcących na żywo śledzić obrady oraz wziąć udział w dyskusji nad podejmowanymi zagadnieniami. 